\title{
THE RATEL MICVs
}

\section{Lt H.W. Kleinecke*}

\section{Introduction}

The UN arms embargo and the increasing military threat to South Africa's security during the 1960 's and early 1970's forced South Africa to establish its own arms industry. The Armaments Corporation of South Africa (Armscor) which was instituted in 1968 was given the task of coordinating the development of South Africa's militaryindustrisl infrastructure in order to produce and provide for the SADF military equipment which matched or bettered that which the country's enemies could muster. It is interesting to note here that all weapon systems are designed and manufactured with the harsh African evironment in mind. For instance, for all military vehicles high mobility is of the utmost importance, and because great distances have to be covered in the African bush, Armscor has developed wheeled vehicles in preference to tracked vehicles. ${ }^{1}$

\section{Development}

Design work on the Ratel began as early as 1968 and was conducted under the auspices of Armscor. The new infantry fighting vehicle was intended to meet the requirements of the South African Infantry Corps and, later also the South African Armoured Corps. They required a vehicle with good armour protection, high road speed, large operational range with a minimum of maintenance, good firepower and good cross-country mobility. The first prototype of the Ratel was completed in July 1974. It was followed by four pre-production vehicles, the first of which was ready in 1976. Subsequently the Ratel went into full production. Over the years the models were modified due to the valuable feedback provided by operations conducted in Namibia and in Angola. $^{2}$

Today there is a family of Ratel Mechanized Infantry Combat Vehicles (MICVs) There are three variations of Ratel combat vehicles, viz the Ratel 20 Infantry fighting Vehicle (IFV), the Ratel 60 IFV and the Ratel 90 Fire Support Vehicle (FSV). They were developed as a range of tactical transport to carry infantry, fighting troops into action and to give them armoured and firing support. A Ratel Command Vehicle has also been developed in order to give the platoon commander of a mechanized infantry platoon better control over situations, especially in battle. The Ratel Logistics Vehicle, which is an 8-wheeled variant was recently brought off the production line. It was developed to meet the logistical requirements of a mechanized infantry unit which operates over extensive areas and periods of time.

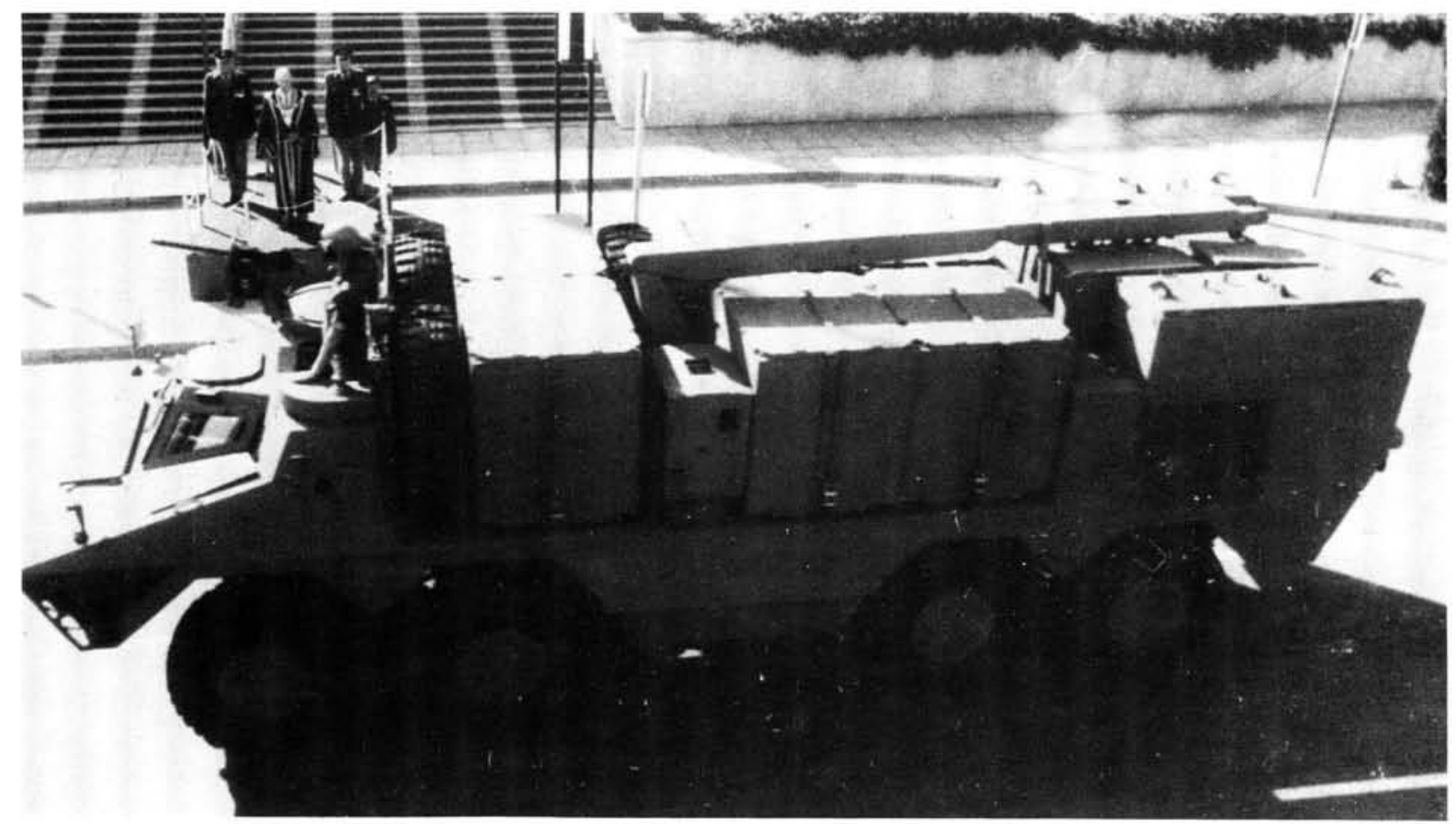

The Ratel 8 × 8 logistic support vehicle (841003493) 
Development of future variants has also been envisaged. These include an ambulance and an $81 \mathrm{~mm}$ mortar carrier. ${ }^{3}$

\section{Armament and ammunition}

Armament varies according to the role to be played by the vehicle in operations. The first version of the series of Ratel combat vehicles, the Ratel $20 \mathrm{IFV}$ is armed with a $20 \mathrm{~mm}$ cannon which is mounted on a small turret together with a coaxially mounted $7,62 \mathrm{~mm}$ machine-gun. The $20 \mathrm{~mm}$ cannon fires three types of ammuniton, vix armour piercing shells, high explosive (HE) and practice rounds. The Ratel $60 \mathrm{IFV}$ also has a two-man turret which is fitted with a $20 \mathrm{~mm}$ mortar and a coaxially mounted $7,62 \mathrm{~mm}$ machinegun. The mortar is breech-loaded and is capable of firing $\mathrm{HE}$, smoke and illuminating bombs to a

\section{General description}

The hull of the Ratel gives protection from small arms fire and shell splinters and protection in the frontal arc against armourpiercing rounds. The vehicle also gives protection against mines. Only the logistical version of this vehicle is fitted with 8 wheels, all the other versions are six-wheeled. All versions have a basic crew of three, viz the driver, who sits in the front of the vehicle, and the commander and main gunner who are seated on the left and right hand side respectively of the two-man turret. The combat vehicles also carry the following personnel: rear anti-aircraft gunner, section commander and infantrymen. The command vehicle carries command post personnel. ${ }^{5}$

Standard equipment of the combat range of Ratels includes a complete set of tools, spades, picks and axes, a tow bar and towing cables, a

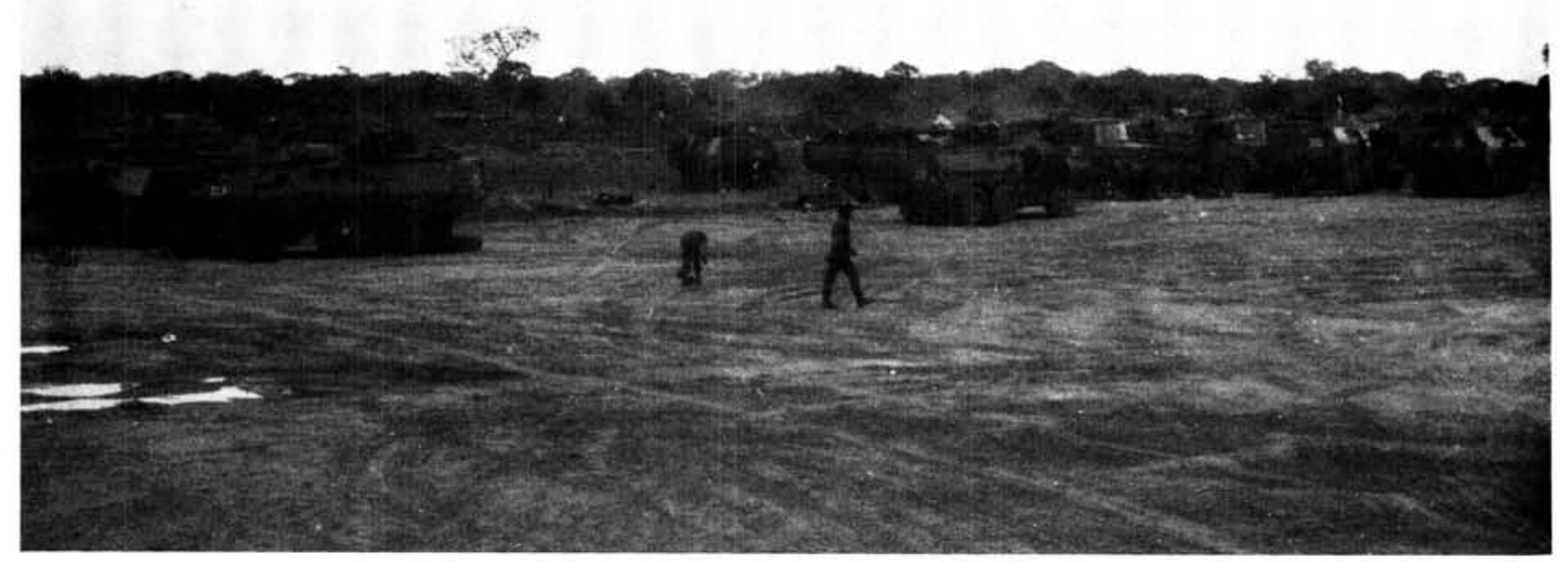

Parked Ratel 90 vehicles and Samil trucks (841001052)

maximum range of 1500 metres. The Ratel 90 FSV is fitted with a $90 \mathrm{~mm}$ semi-automatic quickfiring gun on a two-man turret. As with the Ratel 20 and 60 , a $7,62 \mathrm{~mm}$ machine-gun is mounted coaxially on the turret to its left. The $90 \mathrm{~mm}$ gun fires Heat, HE and practive rounds. A $12,7 \mathrm{~mm}$ M2 HB machine-gun can be mounted over the 90 $\mathrm{mm}$ gun for training purposes. The Ratel 12,7 $\mathrm{mm}$ Command Vehicle is armed with a $12,7 \mathrm{~mm}$ M2 HB machine-gun. All of the latter vehicles are also armed with two $7,62 \mathrm{~mm}$ anti-aircraft machine-guns, one mounted above the turret and the other at the rear left of the vehicles. Also mounted on either side, towards the rear of each of these vehicle's turrets is a bank of two $81 \mathrm{~mm}$ electrically operated smoke dischargers which can be operated by the commander or gunner. The newest model, the Ratel $8 \times 8$ Logistics Vehicle carries one $12,7 \mathrm{~mm}$ anti-aircraft, machine-gun on the front of the vehicle. ${ }^{4}$ first aid kit, two petrol stoves, fire extinguishers, emergency spares, two 50-litre drinking water tanks, two external stowage compartments, radios, intercom and remote handset with 1000 $\mathrm{m}$ of cable. Optional equipment which may be carried/fitted includes night vision equipment and an air conditioning system. ${ }^{6}$

The command vehicle is fitted with 3 radios, a tape recorder having a time injection facility, a civilian combined receiver and cassette recorder in the hull, intercom system, public address system, pneumatic mast and map boards. ${ }^{7}$

The logistic support vehicle is able to carry nine 1 $\times 1.2 \times 1.2$ metre containers. These can carry various kinds of equipment etc, such as armoured ammunition, equipment such as 5-man tents, toilets and showers, a refrigerator and freezer and 800 litres of water. Integral fuel tanks 
in the hull hold 2000 litres of fuel with a hydraulically powered pump which can fill the bunker tanks from an external supply, or fill two vehicles simultaneously on each side of the bunker and can pump fuel from one external bunker to another. Hand pumps are fitted in case of a power failure. Standard equipment includes tanks for fresh water, a generator, 3 spare wheels, spare parts and tools. ${ }^{8}$

All variants can attain a maximum speed of 105 $\mathrm{km} / \mathrm{h}$ (on the open road). The Ratel logistics vehicle, however, is only capable of a maximum speed of $86 \mathrm{~km} / \mathrm{h}$ on the open road. It has a fuel capacity of 560 litres and a maximum range of $700 \mathrm{~km}$ on road or 14 hours travelling cross country. The other variants have a maximum fuel capacity of 430 litres and a maximum range of $1000 \mathrm{~km}$ on road and 14 hours travelling cross country. ${ }^{9}$ duction, operating, maintenance and training costs and the greater reliability and availibility of wheeled armoured vehicles has accounted for the high regard given to them by many of the world's armed forces. ${ }^{10}$

The Ratel can carry the same main armament as that carried by tracked IFVs and it is fitted with vision blocks and firing ports for its compliment of infantrymen thus making it almost as effective as a tracked IFV. In the terrain that the Ratel is used, its mobility and lightness make it a better vehicle than most tracked IFVs. It offers to the infantry significantly improved firepower, mobility, carrying capacity, a mounted fighting capability, (in the large expanses of land, that have to be patrolled by the South African infantry this is of great importance for the conducting of efficient and effective pursuit missions), and protection from small arms fire and shell fragments and splinters.

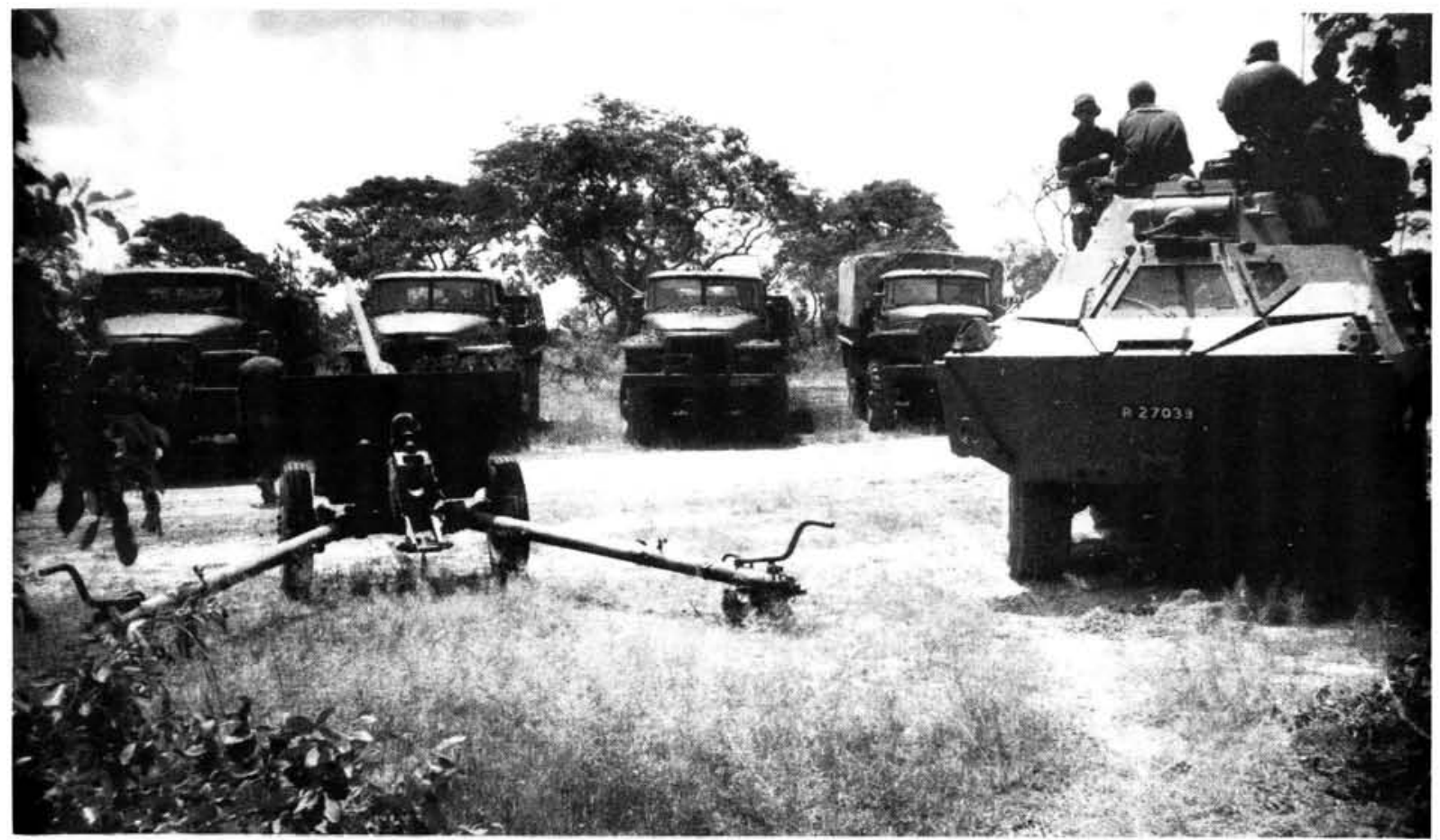

Ratel 20 with captured Soviet "Ural" trucks and an anti-tank gun (841001070)

\section{The efficacy of MICVs}

MICVs such as the Ratel are a hybridized version of tracked IFVs and wheeled Armoured Personnel Carriers (APCs). It was only when vehicles of the calibre and quality of the Ratel emerged with improvements in power trains, suspensions, "run-flat" tyres and the use of more than two axles that their cross-country mobility has been significantly increased and their vulnerability has been reduced to a large extent. The lower pro-
The Ratel's speed, agility and protective function drastically cuts the exposure time of the infantry sections during long assaults over open ground, and the Ratel 90 especially can provide excellent fire support for dismounted infantry.

The employment of the different variants of the Ratel in a mechanized combat unit can provide the infantry with the ability to conduct effective operations over an extensive area for long periods of time. The use of the logistics support 
variant and the command vehicle enables a combat unit to operate as a self-contained and selfsufficient unit far from the home base or headquarters.

\section{Conclusion}

The Ratel family of MICVs have given to the South African infantry the endurance or staying power to conduct long range operations at a greatly reduced cost, with a modicum of comfort, some protection and far greater firepower. The Ratel is a formidable addition to the SADF's armoury. It has swelled the ranks of the infantry giving it greater fighting strength and fighting capability.
*Lt H.W. Kleinecke (B.A. in International Relations and African Political Studies) has just completed his period of National Service at the Military Information bureau.

\section{References}

1. Defence, Vol 15, No 1, January 1984, pp 23-26, John Reed "Armcor - Defence Talks to Commandant P.F. Marais", Whitton Press Ltd, Eton, England, p 23

2. Jane's Armour and Artillery, 1983 - 84; Jane's Publishing Company Ltd, London, New York, p 333

3. Ibid, p 336

4. Ibid, pp $333-336$

5. Ibid, pp $333-335$

6. Ibid, p 334

7. Ibid, pp $334-335$

8. Ibid, list of specifications, $p 336$

9. Marine Corps Gazette, July 1983 - Capt. E.W. Besch, USMC (Ret): "Infantry Fighting Vehicles - Their Evolution and Significance"; Marine Corps Association, Quantico, USA, p 58 